\title{
Saccharomyces boulardii modulates and improves the immune response to Bovine Herpesvirus type 5 Vaccine
}

[Saccharomyces boulardii modula e melhora a resposta imune de vacina contra o Herpes bovino tipo 5]

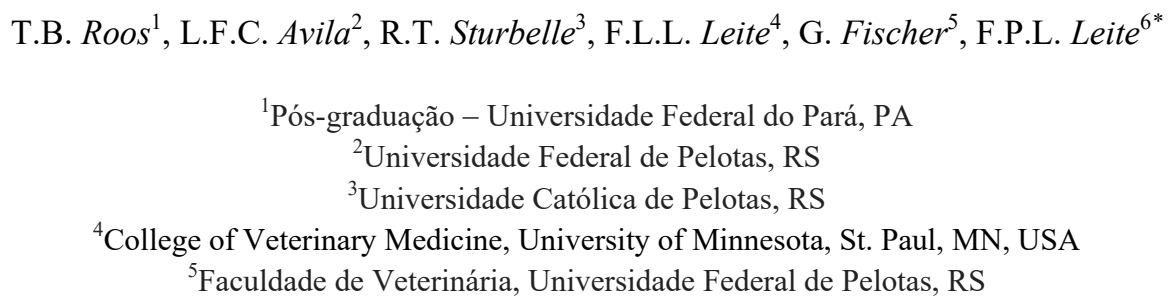

\begin{abstract}
There have been significant efforts towards the development of more efficient vaccines for animal health. A strategy that may be used to improve vaccine efficacy is the use of probiotics to enhance the immune response of the host, leading to increased immunogenicity of antigen preparations. Bovine herpesvirus 5 (BoHV-5) is an example of an important animal pathogen for which vaccines have provided only limited protection. In this study, we examined the use of the probiotic Saccharomyces boulardii ( $S b$ ) as a potential adjuvant to improve vaccine efficiency. We found that the supplemented animals exhibited an enhanced systemic IgG antibody response toward a Th1 response in favor of IgG2a and increased mRNA expression levels of the cytokines IFN-y, IL-12, IL-17 and IL-10 in the spleen. These results suggest that $S b$ supplementation may provide a promising means for improving the efficiency of vaccines, particularly those that rely on a cell-mediated immune response.
\end{abstract}

Keywords: immune modulation, probiotic, cytokines, vaccine

\section{RESUMO}

Esforços significativos têm sido realizados para o desenvolvimento de vacinas mais eficientes em saúde animal. Uma estratégia que pode ser usado para melhorar a eficácia da vacina é o uso de probióticos para melhorar a resposta imune do hospedeiro, conduzindo ao aumento da imunogenicidade de preparações de antígenos. Herpesvírus bovino 5 (BoHV-5) é um exemplo de um importante patógeno animal para os quais vacinas têm fornecido apenas uma protecção limitada. Neste estudo, examinou-se o uso do probiótico Saccharomyces boulardii (Sb) como um adjuvante potencial para melhorar a eficiência da vacina. Verificou-se que os animais suplementados apresentaram uma produção de anticorpos $\operatorname{Ig} G$ superior e com desvio para Th1 em favor de IgG2, além do aumento dos níveis de expressão de mRNA para as citocinas IFN- $\gamma$, IL-12, IL-17 e IL-10. Esses resultados sugerem que a suplementação de Sb pode fornecer um meio promissor para melhorar a eficiência de vacinas, particularmente aquelas que dependem de uma resposta imune mediada por células.

Palavras-chave: imunomodulação, probiótico, citocinas, vacina

\section{INTRODUCTION}

A potential approach for improving vaccine response involves modulating the immune system through the use of probiotics, which are live microorganisms that produce a health benefit when administered at appropriate doses (Erickson and Hubbard, 2000; Schrezenmeir and De Vrese, 2001). The immune modulation mediated by probiotics may be produced by

Recebido em 11 de maio de 2016

Aceito em 3 de fevereiro de 2017

E-mail: fabio@leivasleite.com.br 
different methods, such as leukocyte proliferation, antibody production, phagocyte activity, and changes in cytokine expression (Erickson and Hubbard, 2000, Roos et al., 2012). Saccharomyces boulardii $(\mathrm{Sb})$ is a nonpathogenic yeast that has probiotic properties in humans and animals (Jawhara and Poulain, 2007). Several studies have shown that $S b$ develops its probiotic activity trough several mechanisms, including competition with pathogens for nutrients, inhibition of pathogen adhesion, and enhancement of the immune response (Coppola et al., 2005; Htwe et al., 2008).

Bovine herpesvirus-5 (BoHV-5) is an alphaherpesvirus associated with bovine meningoencephalitis that has been reported in South America, Australia and in other continents (Perez et al., 2003). Although outbreaks of meningoencephalitis can reach a mortality rate of 70-100\% (Riet-Correa et al., 2006), causing important economic losses (Campos et al., 2009), BoHV-5 vaccines remain at an experimental stage of development (Campos et al., 2011).

Only a few studies have tested the potential of $S b$ as an adjuvant to increase vaccine efficacy, and previous studies have not assessed the underlying immune response responsible for potential increases of vaccine responses mediated by $S b$ (Coppola et al., 2005; Roos et al., 2010). The aim of this study was to assess the effect of $S b$ on the immune response of an experimental inactivated vaccine against $\mathrm{BoHV}-5$ in mice.

\section{MATERIALS AND METHODS}

The Saccharomyces boulardii $(S b)$ used in this study was kindly supplied by the Biotechnology Center of the Federal University of Pelotas (UFPel), Brazil. Briefly, the yeast was suspended in sterile saline, seeded on YPD (Yeast Peptone and Dextrose) solidified with $2 \%$ agar (Difco) and incubated for $42 \mathrm{~h}$ at $28^{\circ} \mathrm{C}$. Three to five colonies were then transferred to $500-\mathrm{ml}$ Erlenmeyer flasks containing $150 \mathrm{ml}$ of YPD (Difco) and incubated in an orbital shaker at $200 \mathrm{rpm}$ for $24 \mathrm{~h}$. The cultures were then transferred to a bioreactor (Braun Biotech International CERTOMAT®) containing 91 of YPD medium. The cultures were incubated with a dissolved oxygen concentration of $60 \%$ at
$200 \mathrm{rpm}$ and $28^{\circ} \mathrm{C}$ for $72 \mathrm{~h}$. The cultures were centrifuged at $4000 \times \mathrm{g}$ for $20 \mathrm{~min}$ in a refrigerated centrifuge and suspended to a volume of 11 . The yield of $S b$ obtained in our experiments was $\sim 2.0 \times 10^{9} \mathrm{CFU}^{-\mathrm{ml}}$. Purity controls were performed at all stages of the cultures.

For the first experiment, a total of $20 \mathrm{Balb} / \mathrm{c}$ isogenic female mice (weighing 16-21g) were randomly divided into two groups of 10 animals. The control group was fed a commercial feed without chemotherapeutics, and the probiotic group was fed the same commercial feed supplemented with a suspension of $S b(1 \times$ $10^{7} \mathrm{CFU}^{-\mathrm{g}}$ of feed). The animals were subjected to a feed adaptation period of seven days prior to immunization. The mice were vaccinated subcutaneously with $0.25 \mathrm{ml}$ of an inactivated BoHV-5 experimental vaccine adjuvanted with $10 \%$ aluminum hydroxide at day 0 and revaccinated on day 28 . Blood samples from both groups were collected from the retro-orbital venous sinus during the experimental period. Animal sera was separated from the whole blood and stored at $-20^{\circ} \mathrm{C}$ until analysis. For the second experiment, to evaluate the host immune response to $S b$, a total of $20 \mathrm{Balb} / \mathrm{c}$ isogenic female mice (weighting 16-21g) were randomly divided into two groups of 10 animals. The control group was supplied a chemotherapeuticfree commercial feed, and the probiotic group was fed the same commercial feed supplemented with a $S b$ suspension of $1 \times 10^{7} \mathrm{CFU}^{-\mathrm{g}}$ of feed. The study was replicated in independent experiments. The experiment was approved by the UFPel Institutional Animal Ethics Committee (CEEA n.1981).

The evaluation of total $\mathrm{IgG}$ antibodies against BoHV-5 was performed by ELISA (Dummer et al., 2014). Briefly, plates (Nunc) were sensitized with $50 \mu \mathrm{l}$ of a suspension containing recombinant BoHV-5 glycoprotein $\mathrm{D}$ at a concentration of $2 \mathrm{mg} / \mathrm{ml}$ diluted in carbonatebicarbonate buffer ( $\mathrm{pH} 9.6)$ at $4^{\circ} \mathrm{C}$ for $18 \mathrm{~h}$. The plates were washed three times with phosphate buffered solution ( $\mathrm{pH}$ 7.6) containing $0.5 \%$ Tween 20 (PBS-T). Sera diluted in PBS-T 1/100 were added to the plate wells in duplicate $(50 \mu \mathrm{l}$ /well) and incubated at $37^{\circ} \mathrm{C}$ for $90 \mathrm{~min}$. The plates were then washed three times with PBS-T. Then, $50 \mu$ l of peroxidase-conjugated rabbit antimouse IgG (Dakopatts A/S) diluted 1/2000 in 
PBS-T was added to each well, and the plates were incubated at $37^{\circ} \mathrm{C}$ for $90 \mathrm{~min}$. Immediately following incubation, the plates were washed five times with PBS-T, and $50 \mu \mathrm{l}$ of ophenylenediamine (OPD, Sigma) chromogenic substrate was added, and the mixture was allowed to react in the dark for $15 \mathrm{~min}$ at room temperature. Absorbance readings were conducted using a microplate reader (MR 700 Microplate Reader, Dynatech Laboratories) at $450 \mathrm{~nm}$. Each plate contained two positive (sera from mice previously immunized against BoHV5) and two negative control serum samples, which were used as intra and interplate controls. The absorbances were transformed to ELISA units by dividing the absorbance of each serum by that of the pre-immune serum, and the results are expressed as the total $\mathrm{IgG}$ increase.

The IgG1 and IgG2a isotype levels were evaluated by ELISA using pooled sera (Roos et al., 2012). Briefly, the plates were coated as described for the BoHV-5 ELISA above. Then, $50 \mu \mathrm{l} /$ well of pooled sera diluted $1 / 200$ in PBS-T was added to the wells and plates were incubated at $37^{\circ} \mathrm{C}$ for $90 \mathrm{~min}$. After this period, the plates were washed three times with PBST, and after adding $50 \mu \mathrm{l} /$ well of anti-mouse IgG1 isotype antibody (Sigma) diluted $1 / 10,000$ in PBS, they were incubated at $37^{\circ} \mathrm{C}$ for $120 \mathrm{~min}$. The same protocol was performed using anti-mouse IgG2 isotype antibody.

Spleens from the mice were aseptically removed, and the splenocytes (pooled from five mice from each group) were separated and plated in a 24well microtiter plate at $5 \times 10^{6}$ cells/well. The splenocytes were maintained for $24 \mathrm{~h}$ in RPMI1640 containing $10 \%$ fetal calf serum and stimulated with either $S$. boulardii cells $\left(10^{8} \mathrm{CFU}^{-\mathrm{ml}}\right)$ or concanavalin $\mathrm{A}(5 \mu \mathrm{g} / \mathrm{ml})$. The supernatants were then removed, and the splenocytes were collected in TRIZOL $\mathbb{}$ (Invitrogen) and stored at $-70^{\circ} \mathrm{C}$. The total RNA from the splenocytes was extracted, and cDNA was synthesized following the Invitrogen protocol and then stored at $-20^{\circ} \mathrm{C}$. The gene expression levels were determined by quantitative real-time polymerase chain reaction
(qPCR). The relative amount of mRNA for each gene was determined by the comparative threshold cycle $\left(\Delta \Delta \mathrm{C}_{\mathrm{T}}\right)$ method and normalized to the housekeeping gene beta-actin ( $\beta$-actin). The primers are described elsewhere and were synthesized by MWG-Biotech Inc. (USA): IL-12p40 F, AGCACCAGCTTCTTCATCAGG; IL-12p40 R, CCTTTCTGGTTACACCCCTCC; $\beta$-actin F, AACGCCCTTCATTGAC; $\beta$-actin R, TCCACGACATACTCAGCAC; IL-17 F, GCTCCAGAAGGCCCTCAGA; IL-17 R, AGCTTTCCCTCCGCATTGA; IL-10 F, TTTGAATTCCCTGGGTGAGAA; IL-10 R, ACAGGGGAGAAATCGATGACA; IFN- $\gamma$ F, GCGTCATTGAATCACACCTG; and IFN- $\gamma$ R, TGAGCTCATTGAATGCTTGG.

The means of the IgG fold increases were transformed and then analyzed by repeatedmeasures ANOVA, and a $t$ test was used to compare the means of the qPCR results. In both tests, differences were considered significant at $\mathrm{P}<0.05$.

\section{RESULTS}

The mice from both groups responded to the vaccine, showing increased levels of antibodies. On day 14 , the $S b$ probiotic group showed a mean IgG increase of approximately 5-fold, which is 2.7-fold higher than that observed in the control group (1.8-fold, $\mathrm{P}<0.05)$. On day 28 , the IgG concentrations in the $S b$ probiotic group exhibited an 8.7-fold increase, whereas the control group showed only a 3.6-fold increase $(\mathrm{P}<0.05)$. In the $S b$ group, the $\mathrm{IgG}$ level continued to increase from the $28^{\text {th }}$ to the $42^{\text {nd }}$ day ( 8.7 to 9.6 ), whereas in the control group, the increase in the $\mathrm{IgG}$ levels was lower (3.6 to 5.4 ) $(\mathrm{P}<0.05)$ (Figure 1A).

A $S b$ probiotic effect was also observed in the $\mathrm{IgG}$ isotype profile by day 28 , and this effect was maintained until the end of the experiment. The animals supplemented with the probiotic showed an increased $\mathrm{IgG} 2 \mathrm{a} / \mathrm{IgG} 1$ ratio during the experiment, whereas the control group maintained the same IgG ratio (Figure 1B). 

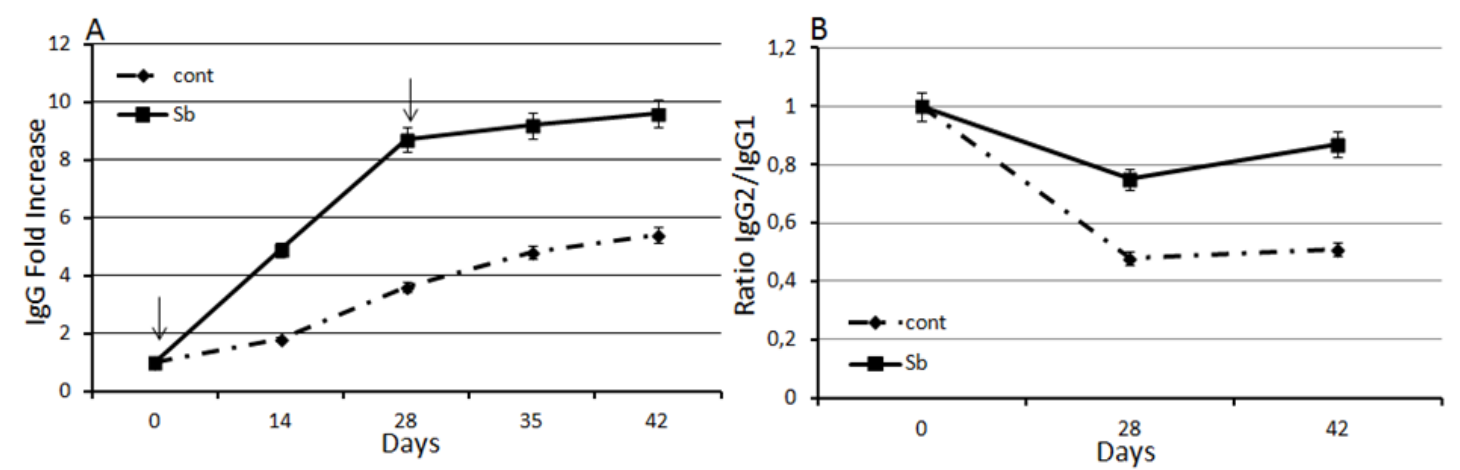

Figure 1. ELISA of serum IgG dynamics. (A) The data represent the means ( $+/-$ standard deviation) of the fold increase in the level of IgG against BoHV-5 from two independent experiments in animals supplemented with $\mathrm{Sb}$ and control mice. The arrows indicate vaccination. At all studied time points, a statistically significant difference $(\mathrm{P}<0.05)$ was observed between the probiotic-supplemented and control groups. (B) The data represent the means of the $\mathrm{IgG} 2 \mathrm{a} / \mathrm{IgG} 1$ ratio against BoHV-5 in animals supplemented with $\mathrm{Sb}$ and control mice. At all studied points, a statistically significant difference $(\mathrm{P}<0.05)$ was observed between the probiotic-supplemented and control groups.

To determine whether the $S b$ effects on the IgG level and isotype were mediated by the cytokine profile induced by the probiotic, we analyzed cytokine gene expression of the splenocytes from mice supplemented with the probiotic and the control mice through qPCR. The $S b$ supplemented group showed increased expression of IFN- $\gamma$, IL-12, IL-10 and IL-17 genes. The mRNA of levels of IFN- $\gamma$ and IL-12 presented significant 40 -fold increases compared the controls, and the IL-10 and IL-17 mRNA levels were 1.3 and 2.5-fold higher, respectively, compared to the controls (Figure 2). Concanavalin A treatment was used as positive control to assess the viability of splenocytes used (data not shown).
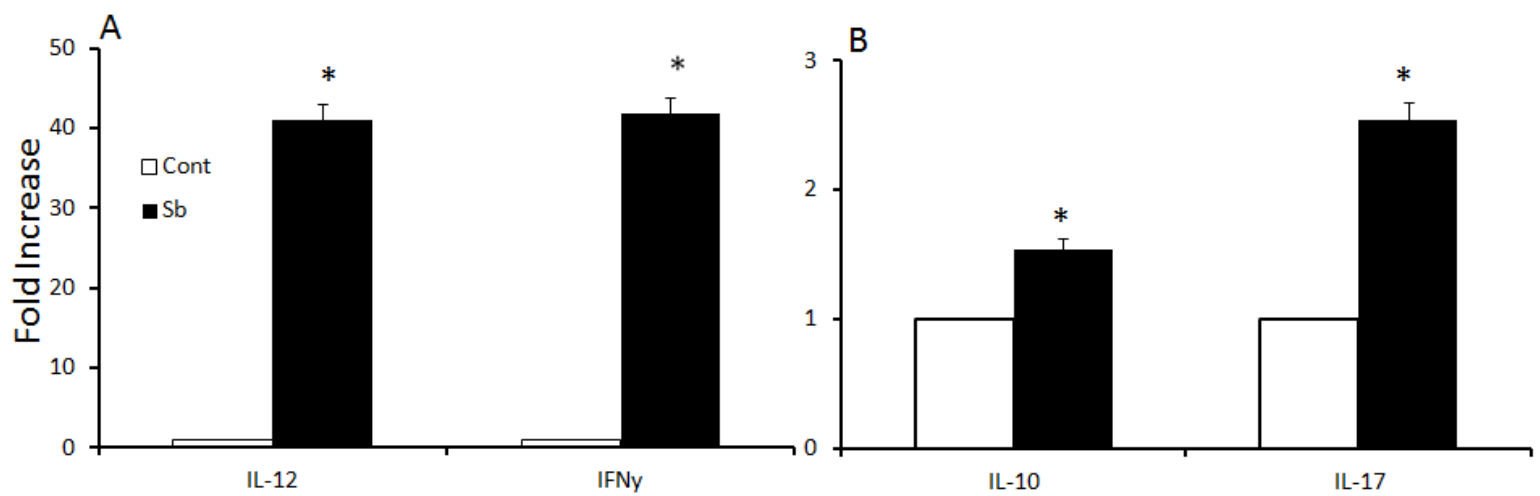

Figure 2. Effect of $S b$ supplementation on cytokine mRNA expression. (A) The data represent the means $(+/-$ standard deviation) of qRT-PCR $(\Delta \Delta \mathrm{CT})$ results of the fold increase in the IL-12 and IFNy mRNA levels from splenocytes stimulated with $S b$ cells. (B) qRT-PCR $(\Delta \Delta C T)$ results of the fold increase in the IL-10 and IL-17 mRNA levels from splenocytes stimulated with $S b$ cells. The asterisks (*) indicate a statistically significant $(\mathrm{P}<0.05)$ difference between the $S b$ supplemented and control (cont) groups.

\section{DISCUSSION}

The use of vaccines for the control of infectious diseases has been one of the major contributions to animal health (Plotkin, 2005). Different approaches for the development of more efficient vaccines have been studied in recent years, and the use of probiotics as adjuvants to enhance vaccine efficiency is a novel and promising approach (Licciardi and Tang, 2011). In this study, we report that supplementation of feed 
with $S b$ enhances the immune response in mice to an inactivated BoHV -5 vaccine.

The IgG antibody titers 14 days after the first vaccine dose were 2.7-fold higher $(\mathrm{P}<0.05)$ in the $S b$-supplemented animals compared to those in the control group. This observation suggests that the $S b$ modulation begins soon after the first vaccine stimulation; this increase also persisted on days 28 and 42 at 2.4-fold higher levels $(\mathrm{P}<0.05)$. Our results also showed variations in the $\mathrm{IgG} 2 \mathrm{a} / \mathrm{IgG} 1$ ratio in animals that were supplemented with $S b$. On day 28 , the ratio in the $S b$ group was 0.75 , suggesting a modulation toward a Th1 response, whereas the control group presented a ratio of 0.48 . On day 48 , the respective ratios were 0.87 and 0.51 . This modulation effect mediated by $S b$ is quite important considering that the adjuvant used in the vaccine was aluminum hydroxide, which induces a Th2 response in mice (De Gregorio et al., 2008; Kool et al., 2008). The inefficiency of aluminum hydroxide as an activator of Th1 responses suggests that additional signals were presented with the antigen to promote an immune response bias toward cell-mediated immunity (Th1/IgG2a) (Wang and Singh, 2011).

The observation of increased antibody levels in animals fed $S b$ is in agreement with results obtained in mice and sheep supplemented with $S b$ and vaccinated against Escherichia coli, parvovirus and BOHV-5 (Coppola et al., 2005; Roos et al., 2010). In this study we pursued to understand the host response involved in the increased antibody levels. One of the mechanisms involved in probiotic-mediated immune modulation may be the capacity of the probiotic to stimulate cytokine production (Le Blanc et al., 2011). Therefore, to verify whether this modulation is mediated by the presence of $\mathrm{Sb}$ during the immunization and whether cytokines play a role in this process, we stimulated splenocytes from mice supplemented with $S b$ with $S b$ cells and used qPCR to evaluate the cytokine expression levels. We observed a significant increase in the mRNA expression levels of IL-12, IFN-y, IL-17 and IL-10 (Figure 2 ), suggesting that these cytokines play a role in the immune modulation mediated by $S b$.

Th1 cells produce IFN- $\gamma$, which plays an important role in protection against intracellular pathogens. The differentiation of Th1 cells requires IL-12, which promotes IFN- $\gamma$ secretion by $\mathrm{T}$ lymphocytes and NK cells and is generally produced by APCs (i.e., DCs) in response to their activation. Because the immune-modulatory effect of $S b$ may occur during the priming activation of APCs by the antigen, the environment in which this encounter occurs is likely an important factor in the establishment of the secondary immune response (Li et al., 2007). Therefore, the cytokines expressed during this process may have a major role in guiding the immune response and influencing the vaccine response (Kaufmann, 2007).

The cytokines IFN- $\gamma$ and IL-12 characterize the development of a Th1 response, suggesting that the probiotic modulatory effect observed on the $\mathrm{IgG}$ isotype profile (IgG2a/IgG1 ratio) may have been the result of this differentiated cytokine expression ( $\mathrm{Li}$ et al., 2007). This effect is of great importance in the vaccine immune response because a cellular immune response is generally required for the control of viral infections (Pinto et al., 2006) and because it is possible to change the aluminum hydroxide adjuvant effect from Th2 to Th1 (Li et al., 2007; De Gregorio et al., 2008; Kool et al., 2008), offering another perspective on the use of $S b$ as adjuvant in viral vaccines.

$\mathrm{T}$ helper type 17 (Th17) cells are highly proinflammatory effector $\mathrm{T}$ cells that are characterized by a unique expression pattern of cytokines and transcription factors including IL17. It was recently demonstrated that Th17 cells not only trigger B-lymphocyte proliferation but also promote the formation of GCs (germinal centers) together with IgG isotype switching (Mitsdoerffera et al., 2010). Mitsdoerffera et al., (2010) demonstrated that that IL-17 alone can drive class switch recombination to IgG2a. Our experiment revealed a 2.5 -fold increase in IL-17 mRNA expression in splenocytes of the $S b$ group compared with those of the control group. Therefore, it is possible to suggest that part of the $S b$ adjuvant effect observed on the antibody dynamics may be due to IL-17.

IL-10 can be produced by several cell types including $\mathrm{T}$ cells, B cells and macrophages and its main function is controlling the intensity of immune responses (Ouyang et al., 2011). Its expression in the $S b$ group is in agreement with its role as a probiotic of controlling inflammatory 
processes (Niers et al., 2005). However, the increase in IL-10 mRNA expression observed in this experiment may have an effect on the levels of IgG observed in supplemented mice (Figure 2). This is because IL-10 plays an important role in the priming and proliferation of $B$ lymphocytes (Ouyang et al., 2011), thus it could have led to higher antibody production in the $S b$ the supplemented group.

\section{CONCLUSION}

In conclusion, the data obtained in this study allow us to conclude that Saccharomyces boulardii has a modulatory effect on the vaccine immune response against BoHV-5 in mice. Thus, the use of this probiotic can contribute significantly to improving the response elicited by conventional vaccines, particularly those that rely on increasing antibody levels and cellmediated immune responses.

\section{REFERENCES}

CAMPOS, F.S.; DEZEN, D.; ANTUNES D.A. et al. Efficacy of an inactivated, recombinant bovine herpesvirus type 5 (BoHV-5) vaccine. Vet. Microbiol., v.148, p.18-26, 2011.

CAMPOS, F.S.; FRANCO, A.C.; HÜBNER, S.O. et al. High prevalence of co-infections with bovine herpesvirus 1 and 5 found in cattle in southern Brazil. Vet. Microbiol., v.139, p.67-73, 2009.

COPPOLA, M.M.; CONCEIÇÃO, F.R.; GILTURNES, C. Effect of Saccharomyces boulardii and Bacillus cereus var. Toyoi on the humoral and cellular response of mice to vaccines. Food Agric. Immunol., v.16, p.213-219, 2005.

DE GREGORIO, E.; TRITTO, E.; RAPPUOLI, R. Alum adjuvanticity: unraveling a century old mystery. Eur. J. Immunol., v.38, p.2068-2071, 2008.

DUMMER, L.A.; ARAUJO, I.L.; FINGER, P.F. et al. Immune responses of mice against recombinant bovine herpesvirus 5 glycoprotein D. Vaccine, v.32, p.2413-2419, 2014.

ERICKSON, L.K.; HUBBARD, E.N. Probiotic immunomodulation in health and disease. $J$. Nutr., v.130, p.403-109, 2000.
HTWE, K.; YEE, K.S., TIN, M.; VANDENPLAS, Y. Effect of Saccharomyces boulardii in the treatment of acute watery diarrhea in myanmar children: a randomized controlled study. Am. J. Trop. Med. Hyg., v.78, p.214-216, 2008.

JAWHARA, S.; POULAIN D. Saccharomyces boulardii decreases inflammation and intestinal colonization by Candida albicans in a mouse model of chemically-induced colitis. Med. Mycol., v.45, p.691-700, 2007.

KAUFMANN, S.H.E. The contribution of immunology to the rational desing of novel antibacterial vaccines. Nat. Rev. Microbiol., v.5, p.491-504, 2007.

KOOL, M.; SOULLI, T.; VAN NIMWEGEN, M. et al. Alum adjuvant boosts adaptive immunity by inducing uric acid and activating inflammatory dendritic cells. J. Exp. Med., p.205, p.869-882, 2008.

LE BLANC, A.M.; CARMEN, S.; ZURITATURK, M. et al. Importance of IL-10 modulation by probiotic microorganisms in gastrointestinal inflammatory diseases. Gastroenterology, v.11, p.731-753, 2011.

LI, H.; NOOKALA, S.; RE, F. Aluminum hydroxide adjuvants activate caspase-1 and induce IL-1 $\beta$ and IL-18 release. J. Immunol., v.178, p.271-276, 2007.

LICCIARDI, P.V.; TANG M.L. Vaccine adjuvant properties of probiotic bacteria. Discov. Med., v.12, p.525-33, 2011.

MITSDOERFFERA, M.; LEEA, Y.; JÄGERA, A. et al. Proinflammatory $\mathrm{T}$ helper type 17 cells are effective B-cell helpers. Proc. Natl. Acad. USA., v107, p.14292-14297, 2010.

NIERS, L.E.M.; TIMMERMAN, H.M.; RIJKERS, G.T. et al. Identification of strong interleukin-10 inducing lactic acid bacteria which down-regulate $\mathrm{T}$ helper typo 2 cytokines. Clin. Exp. Allergy, v.35, p.1481-1489, 2005.

OUYANG, W.; RUTZ, S.; CRELLIN, N.K. et al. Regulation and functions of the IL-10 family of cytokines in inflammation and disease. Annu. Rev. Immunol., v.29, p.71-109, 2011. 
PEREZ, S.E.; VAGNOZZI, A.; SUR, J.H. et al. Retrospective analysis of cases with a diagnosis of cerebrocortical necrosis and its relation with type 5 bovine herpesvirus. Rev. Argent. Microbiol., v.35, p.69-73, 2003.

PINTO, R.A.; ARREDONDO, S.M.; GAGGERO, A.A.; DIAZ, P.V. T helper 1/T helper 2 cytokine imbalance in respiratory syncytial virus infection as associated with increased endogenous plasma cortisol. Pediatrics, v.117, p.878-886, 2006.

PLOTKIN, S.A. Vaccines: past, present and future. Nat. Med., v.11, p.5-11, 2005.

RIET-CORREA, G.; DUARTE, M.D.; BARBOSA, J.D. et al. Meningoencephalitis and poliencefalomalacia caused by bovine herpesvirus-5 in the State of Pará [in Spanish]. Pesqui. Vet. Bras., v.26, p.44-46, 2006.
ROOS, T.B.; LARA, A.P.S.S.; DUMMER, L.A. et al. The imune modulation of Bacillus cereus var. toyoi in mice immunized with experimental inactivated Bovine Herpesvirus Type 5 vaccine. Vaccine, v.30, p.2173-2177, 2012.

ROOS, T.B.; TABELEÃO, V.C.; DUMMER, L.A. Effect of Bacillus cereus var. toyoi and Sacharomycesboulardiion the immune response of sheep to vaccines. Food Agric. Immunol., v.21, p.113-118, 2010.

SCHREZENMEIR, J.; DE VRESE, M. Probiotics, prebiotics and symbiotics: approaching a definition. Am. J. Clin. Nutr., v.73, p.361-364, 2001.

WANG, W.; SINGH, M. Selection of adjuvants for enhanced vaccine potency. World J. Vaccine, v.1, p.33-78, 2011. 